\title{
Use of Lippia rotundifolia and Cymbopogon flexuosus essential oils, individually or in combination, in broiler diets
}

\author{
Izabela Lorena Azevedo ${ }^{1 *}$, Ernane Ronie Martins ${ }^{1}$, Anna Christina de Almeida ${ }^{1}$, Wedson Carlos \\ Lima Nogueira1, Daniel Emygdio de Faria Filho², Vanessa Kelly Ferreira do Rosário Santos', \\ Leonardo José Camargos Lara ${ }^{3}$
}

\footnotetext{
${ }^{1}$ Universidade Federal de Minas Gerais, Instituto de Ciências Agrárias, Montes Claros, MG, Brazil.

2 Universidade de São Paulo, Faculdade de Zootecnia e Engenharia de Alimentos, Pirassununga, SP, Brazil.

${ }^{3}$ Universidade Federal de Minas Gerais, Escola de Veterinária, Belo Horizonte, MG, Brazil.
}

\begin{abstract}
This study investigated the effects of Cymbopogon flexuosus and Lippia rotundifolia microencapsulated essential oils on broiler performance and carcass yield. One hundred and fifty mixed-sex Cobb broiler chicks were used, from one day up to 42 days of age, in a completely randomized design, with five treatments and three replicates of ten birds each. The treatments were: negative control (basal diet), positive control (diet with enramycin and salinomycin), and three diets with microencapsulated essential oils from lemongrass, L. rotundifolia, and combination with $50 \%$ of both. The performance and carcass yield were not affected by the treatments. The intestine absolute weight was lower in the combination treatment compared with the negative control treatment and the lemongrass essential oil. The intestine relative weight was higher in the treatments with lemongrass and L. rotundifolia essential oils in relation to the combination. The liver relative weight was lower with the lemongrass essential oil and the combination compared with the treatment with the L. rotundifolia essential oil. The trial could not find results enough to recommend the use of the lemongrass and L. rotundifolia essential oils as an additive in broiler diets.
\end{abstract}

Key Words: antimicrobials, essential oils, lemongrass, performance

\section{Introduction}

Antimicrobials have been used as additives in poultry for many years, contributing to improved growth performance and feeding efficiency of birds (Agostini et al., 2012). However, concern about the increase in cases of bacterial resistance and residues in products have resulted in the prohibition of performance enhancers by the European Union (Santos et al., 2005). Thus, Brazilian exporters must confirm to the standards, stimulating studies on substitutes for antibiotics, such as plant essential oils and other additives such as organic acids, probiotics, and prebiotics.

Received: March 28, 2016

Accepted: September 26, 2016

*Corresponding author: azevedobella71@yahoo.com.br

http://dx.doi.org/10.1590/S1806-92902017000100003

How to cite: Azevedo, I. L.; Martins, E. R.; Almeida, A. C.; Nogueira, W. C. L.; Faria Filho, D. E.; Santos, V. K. F. R. and Lara, L. J. C. 2017. Use of Lippia rotundifolia and Cymbopogon flexuosus essential oils, individually or in combination, in broiler diets. Revista Brasileira de Zootecnia 46(1):13-19.

Copyright (C) 2017 Sociedade Brasileira de Zootecnia. This is an Open Access article distributed under the terms of the Creative Commons Attribution License (http://creativecommons.org/licenses/by/4.0/), which permits unrestricted use, distribution, and reproduction in any medium, provided the original work is properly cited.
Essential oils and their main compounds can be used as additives and improve broiler performance and intestinal health (Cho et al., 2014). In general, they act by promoting selection for the beneficial microorganisms in the intestine (Traesel et al., 2011).

Cymbopogon flexuosus essential oil is extracted from the leaves of the plant also known as lemongrass. The mixture between neral isomers (citral $\mathrm{b}$ or cis-citral) and geranial (citral a or trans-citral) form citral, which is the major component of lemongrass and gives the essential oil its characteristic aroma, besides various long-known medicinal properties utilized in popular culture, including antimicrobial activity (Adukwu et al., 2012; Desai and Parikh, 2012). Lemongrass essential oil, due to the effect of the citral, can be cytotoxic and genotoxic to human lymphocytes, but is safe if used at low concentrations, under $400 \mu \mathrm{g} / \mathrm{mL}$ (Sinha et al., 2014).

Lippia rotundifolia is an endemic plant to the Brazilian Cerrado, from the area known as the "Serra do Espinhaço". Although little studied, it is a promising species that belongs to the family Verbenaceae. According to Gomide et al. (2013), the major component of its essential oil is $\beta$-myrcene. It also has proven antimicrobial activity (Souza et al., 2015). There are no reports in the literature of the use of these two species as additives in animal feed. Also, when used 
together, the plants can show synergistic effects on the performance of broilers.

Microencapsulation can be made to increase the stability of the essential oils (to circumvent volatility problems) and protect them during processing and feed passage through the stomach (Barreto et al., 2008; Traesel et al., 2011). The objective of this study was to evaluate the effect of the microencapsulated essential oils of lemongrass and $L$. rotundifolia as additives in the diet on performance, carcass yield, and organ weights of broilers.

\section{Material and Methods}

The research was conducted in Montes Claros, Minas Gerais, Brazil, between January and February, 2015. The procedures were performed in accordance with ethical standards and approved by the Ethics Committee on Animal Usage of the Universidade Federal de Minas Gerais.

The 150 one-day-old Cobb $500^{\circledR}$ chicks were used, mixed, housed in 30 cages $(60 \times 35 \times 100 \mathrm{~cm})$ with feeders and waterers. The experiment was conducted in a completely randomized design, with five treatments and three replicates of 10 animals. The treatments were: negative control, without antimicrobials and anticoccidials; positive control - feed supplemented with 10 ppm enramycin and 42 ppm salinomycin; lemongrass - feed containing $120 \mathrm{mg}$ of lemongrass essential oil for each $\mathrm{kg}^{-1}$ of animal body weight; L. rotundifolia - feed containing $120 \mathrm{mg}$ of L. rotundifolia essential oil for each $\mathrm{kg}^{-1}$ of animal body weight; combination - feed with the mixture of the two essential oils. The dose used was defined from the antimicrobial activity presented by the essential oils of $L$. rotundifolia (Souza et al., 2015) and lemongrass (Azevedo et al., 2016) in preliminary in vitro tests.

The nutrition plan was divided into three phases: starter (1-21 days), grower (22-33 days), and finisher (3442 days). The diets were formulated to meet nutritional levels recommended by Rostagno et al. (2011) and offered ad libitum throughout the experimental period in a mashed form (Table 1).

The lemongrass essential oil was acquired from the Ferquima Industry and Trade LTD company (Vargem Grande Paulista, SP, Brazil) and the L. rotundifolia oil was purchased from producers of the Fundação Universidade do Vale do Jequitinhonha Cooperativa (Serro, district of São Gonçalo do Rio das Pedras, Minas Gerais, Brazil), both extracted by the steam distillation method and packaged in $500-\mathrm{mL}$ bottles.

Analysis of the chemical composition of the oils was conducted by gas chromatography mass spectrometry
(GC-MS) using an Agilent Technologies system (7890A) interfaced with a mass spectrometer (MS 5975C) equipped with DB-5ms capillary column $(30 \mathrm{~m} \times 0.25 \mathrm{~mm} \times 0.25 \mu \mathrm{m})$ with helium $\left(1 \mathrm{~mL} \cdot \mathrm{min}^{-1}\right)$ as carrier gas. The injector was maintained at $220^{\circ} \mathrm{C}$, following the temperature program of $60{ }^{\circ} \mathrm{C}-240{ }^{\circ} \mathrm{C}\left(3{ }^{\circ} \mathrm{C} \mathrm{min}-1\right)$, operating at an electron impact of $70 \mathrm{eV}$ in a range of 45 to $550 \mathrm{~m} / \mathrm{z}$. The identification of essential oil constituents was made using the MSD Chemstation software with the library (National Institute of Standards and Technology, NIST 2002). The relative abundance (\%) of constituents was calculated from the peak area of the chromatogram (GC) and organized according to the elution order.

Table 1 - Composition of experimental diets

\begin{tabular}{|c|c|c|c|}
\hline & Starter & Grower & Finisher \\
\hline \multicolumn{4}{|l|}{ Ingredient ( $\left.\mathrm{g} \mathrm{kg}^{-1}\right)$} \\
\hline Corn & 541.00 & 571.89 & 602.64 \\
\hline Soybean meal $46 \%$ & 374.90 & 337.50 & 302.00 \\
\hline Soy oil & 44.90 & 51.53 & 56.52 \\
\hline Dicalcium phosphate & 15.71 & 13.38 & 11.18 \\
\hline Calcitic limestone & 9.10 & 8.65 & 7.78 \\
\hline Common salt & 4.83 & 4.58 & 4.46 \\
\hline DL-methionine & 1.47 & 1.42 & 1.32 \\
\hline L-lysine & 0.64 & 0.75 & 1.02 \\
\hline Choline chloride & 0.55 & 0.50 & 0.37 \\
\hline Mineral Premix ${ }^{1}$ & 0.50 & 0.50 & 0.50 \\
\hline Vitamin Premix ${ }^{2}$ & 0.40 & 0.30 & 0.20 \\
\hline Inert & 6.00 & 9.00 & 12.00 \\
\hline Total & 1000.00 & 1000.00 & 1000.00 \\
\hline \multicolumn{4}{|l|}{ Additives $\left(\mathrm{mg} \mathrm{kg}^{-1}\right)$} \\
\hline Coccidiostat $^{3}$ & 500 & 500 & 500 \\
\hline Antimicrobial $^{4}$ & 125 & 125 & 125 \\
\hline Capim-limão essential oil ${ }^{5}$ & 2100 & 5000 & 6330 \\
\hline Lippia rotundifolia essential oil ${ }^{5}$ & 2100 & 5000 & 6330 \\
\hline $\begin{array}{l}\text { Capim-limão/Lippia } \\
\text { rotundifolia essential oil }{ }^{6}\end{array}$ & 1050 & 2510 & 3170 \\
\hline \multicolumn{4}{|l|}{ Calculated content } \\
\hline Crude protein $(\%)$ & 21.25 & 19.84 & 18.43 \\
\hline Metabolizable energy ( $\mathrm{kcal} \mathrm{kg}^{-1}$ ) & 3069.92 & 3165.93 & 3215.51 \\
\hline Available phosphorus (\%) & 0.40 & 0.35 & 0.30 \\
\hline Calcium (\%) & 0.84 & 0.75 & 0.66 \\
\hline Sodium $(\%)$ & 0.21 & 0.20 & 0.20 \\
\hline Lysine (\%) & 1.22 & 1.13 & 1.06 \\
\hline Methionine (\%) & 0.48 & 0.45 & 0.43 \\
\hline
\end{tabular}

${ }^{1}$ Mineral Premix containing, per $1 \mathrm{~kg}$ of product: $\mathrm{Cu}(\mathrm{min}), 15 \mathrm{~g} \cdot \mathrm{kg}^{-1} ; \mathrm{Fe}(\mathrm{min})$, 100 g.kg- ${ }^{-1}$ Mn (min), 140 g. $\mathrm{kg}^{-1} ; \mathrm{Zn}$ (min), 100 g.kg ${ }^{-1}$ I (min), 2,400 mg.kg-1 ; Se (min), $400 \mathrm{mg} \cdot \mathrm{kg}^{-1}$; inclusion of $500 \mathrm{~g} / \mathrm{t}$ of feed.

${ }^{2}$ Initial vitamin Premix containing per kg ${ }^{-1}$ of product: vitamin A (min), 14,000,000.00 IU. $\mathrm{kg}^{-1}$; vitamin D3 (min), 4,400,000.00 IU. $\mathrm{kg}^{-1}$; vitamin E (min), 22,000.00 IU. $\mathrm{kg}^{-1}$; vitamin. K3 (min), 3,200.00 mg. $\mathrm{kg}^{-1}$; vitamin B1 (min), 4,000.00 mg. $\mathrm{kg}^{-1}$; vitamin B2 (min), 10,000.00 mg. $\mathrm{kg}^{-1}$; vitamin B6 (min), 6,000.00 mg. $\mathrm{kg}^{-1}$; vitamin

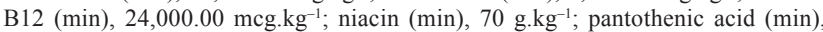

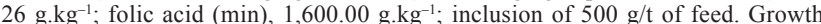
Vitamin Premix containing per $\mathrm{kg}^{-1}$ of product: vitamin A (min), 12,000,000.00 IU. $\mathrm{kg}^{-1}$; vitamin D3 (min), 4,000,000.00 IU. $\mathrm{kg}^{-1}$; vitamin E (min), 20,000.00 IU. $\mathrm{kg}^{-1}$; vitamin K3 (min), 3,200.00 mg. $\mathrm{kg}^{-1}$; vitamin B1 (min), 2,800.00 mg. $\mathrm{kg}^{-1}$; vitamin B2 (min), 8.000.00 mg.kg-1; vitamin B6 (min), 4,000.00 mg. $\mathrm{kg}^{-1}$; vitamin $\mathrm{B} 12$ (min), 20,000.00 mcg. $\mathrm{kg}^{-1}$; niacin (min), $60 \mathrm{~g} . \mathrm{kg}^{-1}$; pantothenic acid (min), 22 g.kg-1; folic acid (min), 1,200.00 g. kg ${ }^{-1}$

${ }^{3}$ Salinomycin coccidiostat for all phases, at $500 \mathrm{~g} / \mathrm{t}$ of feed.

${ }^{4}$ Antimicrobial enramycin for all phases, at $125 \mathrm{~g} / \mathrm{t}$ of feed.

${ }^{5}$ Essential oil of Cymbopogon flexuosus/Lippia rotundifolia in the corresponding treatments.

${ }^{6} \mathrm{Number}$ of each of the essential oils in the association treatment. 
Subsequently, the oils were converted into microcapsules by the Croma Microencapsulados company (São Paulo, SP, Brazil) via the coacervation method with edible polymers.

After microencapsulation and inclusion to diet, new analysis was done to verify the permanence of the essential oil compounds. For the analysis of the volatiles, the feed was transferred to headspace-type glass vials $(20 \mathrm{~mL})$ and placed in the autosampler system (HS combi-PAL). The vial contents were homogenized $(500 \mathrm{rpm})$, incubated $\left(75^{\circ} \mathrm{C}\right.$ for $5 \mathrm{~min})$ and subsequently injected $(1000 \mu \mathrm{L})$ with a pre-heated syringe $\left(75^{\circ} \mathrm{C}\right)$. For identification of volatiles, analysis was performed using Agilent Technologies system (7890A), coupled with mass spectrometry (MS 5975C), fitted with a DB-5ms fused silica capillary column $(30 \mathrm{~m} \times$ $0.25 \mathrm{~mm} \times 0.25 \mu \mathrm{m}$ ) and helium (flow of $1 \mathrm{~mL} \cdot \mathrm{min}^{-1}$ ) as carrier gas. The programming was $35{ }^{\circ} \mathrm{C}$ for $2 \mathrm{~min}$, at $2{ }^{\circ} \mathrm{C} / \mathrm{min}$ up to $80{ }^{\circ} \mathrm{C}$, then $4{ }^{\circ} \mathrm{C} \min ^{-1}$ up to $150{ }^{\circ} \mathrm{C}$, for a total chromatographic run of $42 \mathrm{~min}$. The column was heated at $300{ }^{\circ} \mathrm{C}$ during $1 \mathrm{~min}$ for cleaning. The system operated in scan mode (monitoring) with electron impact at $70 \mathrm{eV}$, in a range of 45 to $550 \mathrm{~m} / \mathrm{z}$. The identification of volatiles was performed by MSD Chemstation software for comparison of the mass spectrum with the library (National Institute of Standards and Technology, NIST 2002).
The birds and feed leftovers were weighed on the first day of the experiment and at 7, 21, 33, and 42 days of age. The variables analyzed were average body weight (BW), weight gain, feed intake, and feed conversion ratio (the relationship between intake and gain, calculated by BW gain/feed intake) of each phase. In the total period of the experiment, we calculated the production viability (VC), by the difference between the total number of housed birds and the number of dead birds, divided by the total birds housed and multiplied by 100 , and productive efficiency index (PEI), through the daily average weight gain multiplied by the production viability and divided by the feed conversion multiplied by 10 .

After 43 days, two birds of each experimental treatment were selected (one male and one female, weighing up to $10 \%$ above or below the average weight), after fasting for $8 \mathrm{~h}$, then slaughtered by bleeding from the jugular vein, scalded, plucked, eviscerated, and then the commercial cuts were separated. Yields assessed were: carcass; breast; thighs + drumsticks; wings; back; feet; relative and absolute weight of the organs (intestine, caecum, liver, pancreas, gizzard, bursa, spleen, heart, and abdominal fat), plus the length of the intestines. Carcass yield was obtained by the ratio of hot carcass weight (gutted) and the fasting weight of the bird. The remaining yields were obtained by the ratio of the weight of the parts and the hot carcass weight.

Table 2 - Relative abundance (\%) of the compounds detected in the essential oils of Cymbopogon flexuosus and Lippia rotundifolia by gas chromatography coupled to mass spectrometry

\begin{tabular}{|c|c|c|c|c|}
\hline \multirow{2}{*}{ Number of peak } & \multirow{2}{*}{$\begin{array}{l}\text { Retention time } \\
\text { (minutes) }\end{array}$} & \multirow{2}{*}{ Compound } & \multicolumn{2}{|c|}{$\%$ Total ions chromatogram ${ }^{1}$} \\
\hline & & & Cymbopogon flexuosus & Lippia rotundifolia \\
\hline 1 & 6.3 & Camphene & 0.03 & ND \\
\hline 2 & 6.9 & Myrcene & ND & 15.52 \\
\hline 3 & 7.2 & 6-methyl-5-hepten-2-one & 0.07 & ND \\
\hline 4 & 7.4 & $\alpha$-phellandrene & ND & 1.65 \\
\hline 5 & 10.1 & Unknown & ND & 5.57 \\
\hline 6 & 10.7 & $\beta$-linalool & 1.17 & 1.68 \\
\hline 7 & 12.6 & 2,4 dimethyl 2,6-octadiene & ND & 13.69 \\
\hline 8 & 12.8 & Tagetone & ND & 11.86 \\
\hline 9 & 14.6 & Unknown & 0.68 & ND \\
\hline 10 & 16.1 & Verbenone & ND & 3.50 \\
\hline 11 & 16.5 & Berbenone & ND & 3.82 \\
\hline 12 & 17.2 & $\beta$-citral & 33.80 & ND \\
\hline 13 & 17.6 & Trans-geraniol & 6.06 & ND \\
\hline 14 & 18.5 & $\alpha$-citral & 43.62 & ND \\
\hline 15 & 23.1 & Geraniol acetate & 4.20 & ND \\
\hline 16 & 24.7 & Caryophyllene & 2.15 & 6.54 \\
\hline 17 & 27.1 & $\gamma$-elemene & ND & 5.60 \\
\hline 18 & 27.7 & $\alpha$-cedrene & ND & 4.20 \\
\hline 19 & 28.5 & $\gamma$-cadinene & 0.33 & ND \\
\hline 20 & 29.2 & Elemol & ND & 2.81 \\
\hline Total & & & 92.10 & 76.50 \\
\hline Trace $^{2}$ & & & 7.80 & 23.49 \\
\hline
\end{tabular}

\footnotetext{
${ }^{1}$ Relative area obtained of the total ions chromatogram.

${ }^{2}$ Trace compounds correspond to those under $1 \%$ of the peak area of the total ion chromatogram.

ND - compound not detected in the analysis.
} 
Data of performance, carcass yield, and organ weights were subjected to analysis of variance and means were compared by Tukey test at 0.05 probability.

\section{Results and Discussion}

The major component of lemongrass was citral $(77.42 \%)$, a mixture of the neral ( $\beta$-citral) and geranial ( $\alpha$-citral) isomers detected in less abundance in the works of Adukwu et al. (2012) and Agnolin et al. (2014), who observed $80 \%$ and $90.6 \%$ citral, respectively.

The compound found in highest abundance in $L$. rotundifolia oil was $\beta$-myrcene $(15.52 \%$ ) (Table 2$)$. The results agree with those obtained by Gomide et al. (2013), who detected $\beta$-myrcene (18.48\%) as the major component of L. rotundifolia originating from Juiz de Fora, MG.

Analysis by gas chromatography using the headspace system was carried out to evaluate the persistence of the components in the feed (Table 3). The compounds detected in the essential oils prior to microencapsulation remained after the process, as well as after incorporation in the feed. Even storage for ten days did not impair the composition of the oils. In the feed with combination of the two essential oils, component characteristic of both species used were detected.

Animal health is directly linked to the balance of intestinal microflora. Naturally, beneficial and pathogenic microorganisms colonize the gastrointestinal tract of

Table 3 - Main compounds detected in the essential oils of Cymbopogon flexuosus and Lippia rotundifolia after microencapsulation and incorporation in feed

\begin{tabular}{|c|c|c|c|c|c|c|c|c|}
\hline \multirow{2}{*}{$\begin{array}{l}\text { Number } \\
\text { of peak }\end{array}$} & \multirow[b]{2}{*}{ Compound } & \multirow{2}{*}{$\begin{array}{l}\text { Retention } \\
\text { time }\end{array}$} & \multirow{2}{*}{$\begin{array}{l}\text { Retention } \\
\text { index }\end{array}$} & \multicolumn{5}{|c|}{ Sample } \\
\hline & & & & LrEO & CfEO & $\begin{array}{l}\text { Control feed }+ \\
\text { CfEO }\end{array}$ & $\begin{array}{c}\text { Control feed }+ \\
\text { LrEO }\end{array}$ & $\begin{array}{l}\text { Control feed }+ \\
\text { LrEO }+ \text { CfEO }\end{array}$ \\
\hline 2 & 4-heptanone & 10.2 & 872 & ND & $\mathrm{D}$ & ND & ND & ND \\
\hline 3 & Tricyclene & 12.9 & & ND & $\mathrm{D}$ & ND & ND & ND \\
\hline 4 & $\alpha$-pinene & 13.7 & 917 & $\mathrm{D}$ & $\mathrm{D}$ & ND & ND & ND \\
\hline 7 & $\beta$-myrcene & 19.3 & 988 & $\mathrm{D}$ & $\mathrm{D}$ & $\mathrm{D}$ & $\mathrm{D}$ & $\mathrm{D}$ \\
\hline 8 & 4-carene & 19.3 & 1002 & ND & $\mathrm{D}$ & ND & ND & ND \\
\hline 9 & $\alpha$-phellandrene & 19.7 & 1007 & $\mathrm{D}$ & ND & ND & $\mathrm{D}$ & ND \\
\hline 10 & $\rho$-cymene & 19.9 & 1021 & ND & $\mathrm{D}$ & ND & ND & ND \\
\hline 11 & 2-carene & 20.0 & 1021 & $\mathrm{D}$ & ND & ND & ND & ND \\
\hline 12 & D-limonene & 20.3 & 1028 & ND & ND & ND & ND & ND \\
\hline 18 & Perylene & 25.2 & 1101 & ND & $\mathrm{D}$ & ND & ND & ND \\
\hline 19 & $\beta$-linalool & 25.9 & 1104 & $\mathrm{D}$ & $\mathrm{D}$ & $\mathrm{D}$ & ND & $\mathrm{D}$ \\
\hline 20 & Trans-p-menta-2,8-dienol & 26.7 & 1118 & ND & $\mathrm{D}$ & ND & ND & ND \\
\hline 21 & (4E,6Z)-2,6-dimethyl-2,4,6-octatriene & 27.2 & 1131 & ND & $\mathrm{D}$ & ND & ND & ND \\
\hline 22 & Trans-tagetone & 29.1 & 1144 & $\mathrm{D}$ & ND & ND & ND & $\mathrm{D}$ \\
\hline 23 & p-menth-1-en-4-ol & 30.1 & 1177 & $\mathrm{D}$ & ND & ND & ND & ND \\
\hline 24 & p-menth-1-en-8-ol & 30.8 & 1190 & $\mathrm{D}$ & ND & ND & ND & ND \\
\hline 25 & D-verbenone & 32.5 & 1205 & $\mathrm{D}$ & ND & ND & ND & ND \\
\hline 26 & Hxenyl valerate & 33.0 & 1244 & $\mathrm{D}$ & ND & ND & ND & ND \\
\hline 27 & Neral & 33.1 & 1249 & ND & $\mathrm{D}$ & $\mathrm{D}$ & ND & $\mathrm{D}$ \\
\hline 28 & Geraniol & 33.2 & 1267 & $\mathrm{D}$ & $\mathrm{D}$ & ND & ND & ND \\
\hline 29 & Geranial & 33.9 & 1269 & $\mathrm{D}$ & $\mathrm{D}$ & $\mathrm{D}$ & ND & ND \\
\hline 38 & $\alpha$-curcumene & 41.6 & 1483 & $\mathrm{D}$ & ND & ND & ND & ND \\
\hline
\end{tabular}

LrEO - microencapsulated essential oil of Lippia rotundifolia; CfEO - microencapsulated essential oil of Cymbopogon flexuosus; D - compound detected in the analysis; $\mathrm{ND}$ - compound not detected in the analysis. 
poultry. The beneficial microorganisms can collaborate in the synthesis of vitamins, reduce gas production, improve digestion and nutrient absorption, and inhibit the growth of pathogenic bacteria. However, the imbalance of microflora leads to an increase of pathogenic microorganisms that can cause much harm to the animal (diseases, mucosal lesions, digestion process deterioration) (Furlan et al., 2004). Essential oils can ensure the balance of the microflora and, consequently, the animal health (Cho et al., 2014).

Body weight, weight gain, feed intake, feed conversion, and productive efficiency indices (Table 4) were not statistically different among treatments $(\mathrm{P}>0.05)$. Good hygiene and management practiced during animal rearing may have contributed to their low quantity of pathogenic microorganisms in the intestine, not worsening even in the negative control. Mortality $(0.0 \%)$ and production viability $(100 \%)$, which were similar among treatments, confirm the good experimental conditions. According to Freitas et al. (2001), the significant effects of the use of performance enhancers are best perceived when animals are subjected to hygiene-challenge conditions, with high population density, high contamination risk, poor hygiene, and exposure to diseases. The same applies to the use of essential oils. As a result, the lack of effect on performance

Table 4 - Performance of broilers fed diets containing essential oils of Cymbopogon flexuosus and Lippia rotundifolia

\begin{tabular}{|c|c|c|c|c|c|c|c|}
\hline Variable & $\begin{array}{l}\text { Negative } \\
\text { control }^{1}\end{array}$ & $\begin{array}{l}\text { Positive } \\
\text { control }^{2}\end{array}$ & Feed $+\mathrm{CfEO}^{3}$ & Feed $+\mathrm{LrEO}^{4}$ & $\begin{array}{c}\text { Feed }+ \\
\mathrm{CfEO}+\mathrm{LrEO}^{5}\end{array}$ & P-value & $\mathrm{CV}(\%)$ \\
\hline \multicolumn{8}{|c|}{ Initial (1-21 days) } \\
\hline Body weight (g) & $707.33 \mathrm{NS}$ & $708.90 \mathrm{NS}$ & $712.27 \mathrm{NS}$ & $727.40 \mathrm{NS}$ & $689.73 \mathrm{NS}$ & 0.09 & 6.51 \\
\hline Feed intake $(\mathrm{g})$ & $883.33 \mathrm{NS}$ & $961.73 \mathrm{NS}$ & 839.20NS & $908.93 \mathrm{NS}$ & $912.00 \mathrm{NS}$ & 0.28 & 7.14 \\
\hline Weight gain $(\mathrm{g})$ & $671.12 \mathrm{NS}$ & $672.44 \mathrm{NS}$ & $676.22 \mathrm{NS}$ & 692.19NS & $654.33 \mathrm{NS}$ & 0.89 & 6.83 \\
\hline Feed conversion ratio (g:g) & $1.31 \mathrm{NS}$ & $1.42 \mathrm{NS}$ & $1.25 \mathrm{NS}$ & $1.31 \mathrm{NS}$ & $1.39 \mathrm{NS}$ & 0.38 & 8.17 \\
\hline \multicolumn{8}{|c|}{ Growth (1-33 days) } \\
\hline Body weight (g) & $1664.6 \mathrm{NS}$ & $1736.20 \mathrm{NS}$ & $1771.00 \mathrm{NS}$ & $1796.07 \mathrm{NS}$ & $1753.17 \mathrm{NS}$ & 0.10 & 3.08 \\
\hline Feed intake $(\mathrm{g})$ & $2514.2 \mathrm{NS}$ & $2566.20 \mathrm{NS}$ & 2394.90NS & $2603.70 \mathrm{NS}$ & $2468.80 \mathrm{NS}$ & 0.49 & 5.94 \\
\hline Weight gain $(\mathrm{g})$ & $1628.45 \mathrm{NS}$ & $1699.74 \mathrm{NS}$ & $1734.95 \mathrm{NS}$ & $1760.86 \mathrm{NS}$ & $1717.76 \mathrm{NS}$ & 0.10 & 3.15 \\
\hline Feed conversion ratio (g:g) & $1.54 \mathrm{NS}$ & $1.51 \mathrm{NS}$ & $1.38 \mathrm{NS}$ & $1.47 \mathrm{NS}$ & $1.43 \mathrm{NS}$ & 0.26 & 6.04 \\
\hline \multicolumn{8}{|c|}{ Final (1-42 days) } \\
\hline Body weight (g) & $2502.67 \mathrm{NS}$ & $2510.67 \mathrm{NS}$ & $2407.07 \mathrm{NS}$ & $2475.83 \mathrm{NS}$ & $2332.67 \mathrm{NS}$ & 0.13 & 3.51 \\
\hline Feed intake $(\mathrm{g})$ & 4135.40NS & $4130.20 \mathrm{NS}$ & $3933.20 \mathrm{NS}$ & $4250.60 \mathrm{NS}$ & 3979.10NS & 0.42 & 5.30 \\
\hline Weight gain $(\mathrm{g})$ & $2466.45 \mathrm{NS}$ & $2474.20 \mathrm{NS}$ & $2371.28 \mathrm{NS}$ & $2440.62 \mathrm{NS}$ & $2297.25 \mathrm{NS}$ & 0.12 & 3.54 \\
\hline Feed conversion ratio ( $\mathrm{g}: \mathrm{g})$ & $1.67 \mathrm{NS}$ & $1.66 \mathrm{NS}$ & $1.66 \mathrm{NS}$ & $1.74 \mathrm{NS}$ & $1.73 \mathrm{NS}$ & 0.24 & 3.04 \\
\hline Productive efficiency index $(\%)$ & $350.40 \mathrm{NS}$ & $353.28 \mathrm{NS}$ & $340.67 \mathrm{NS}$ & $333.81 \mathrm{NS}$ & $315.90 \mathrm{NS}$ & 0.05 & 4.15 \\
\hline
\end{tabular}

${ }^{1}$ Feed negative control without additives.

${ }^{2}$ Feed positive control with antimicrobials and anticoccidials.

${ }^{3}$ Control feed + essential oil of Cymbopogon flexuosus.

${ }^{4}$ Control feed + essential oil of Lippia rotundifolia.

${ }^{5}$ Control feed + association of Cymbopogon flexuosus and Lippia rotundifolia essential oils.

$\mathrm{CV}$ - coefficient of variation; NS - not significant by the Tukey test at $5 \%$ probability.

Table 5 - Carcass and cut yields of broilers fed diets containing essential oils of Cymbopogon flexuosus and Lippia rotundifolia at 43 days of age

\begin{tabular}{|c|c|c|c|c|c|c|c|}
\hline Variable & $\begin{array}{l}\text { Negative } \\
\text { control }^{1}\end{array}$ & $\begin{array}{l}\text { Positive } \\
\text { control }^{2}\end{array}$ & Feed $+\mathrm{CfEO}^{3}$ & Feed $+\mathrm{LrEO}^{4}$ & $\begin{array}{c}\text { Feed }+ \\
\mathrm{CfEO}+\mathrm{LrEO}^{5}\end{array}$ & P-value & CV $(\%)$ \\
\hline Weight after fasting (g) & $2321.67 \mathrm{NS}$ & $2406.67 \mathrm{NS}$ & $2338.67 \mathrm{NS}$ & $2392.67 \mathrm{NS}$ & $2302.00 \mathrm{NS}$ & 0.77 & 7.13 \\
\hline Hot carcass weight (g) & $1809.75 \mathrm{NS}$ & $1933.40 \mathrm{NS}$ & $1800.57 \mathrm{NS}$ & $1853.51 \mathrm{NS}$ & $1787.06 \mathrm{NS}$ & 0.37 & 7.53 \\
\hline Carcass yield $(\%)$ & $78.35 \mathrm{NS}$ & $80.35 \mathrm{NS}$ & $77.08 \mathrm{NS}$ & $77.52 \mathrm{NS}$ & $77.55 \mathrm{NS}$ & 0.77 & 6.13 \\
\hline \multicolumn{8}{|c|}{ Weight of the cuts in relation to the carcass $(\%)$} \\
\hline Breast & $31.85 \mathrm{NS}$ & $31.89 \mathrm{NS}$ & $32.90 \mathrm{NS}$ & $33.35 \mathrm{NS}$ & $33.92 \mathrm{NS}$ & 0.08 & 4.42 \\
\hline Thigh + drumstick & $26.79 \mathrm{NS}$ & $26.64 \mathrm{NS}$ & $25.45 \mathrm{NS}$ & $27.88 \mathrm{NS}$ & $27.26 \mathrm{NS}$ & 0.38 & 7.91 \\
\hline Wings & $8.95 \mathrm{NS}$ & $9.23 \mathrm{NS}$ & $9.73 \mathrm{NS}$ & $9.42 \mathrm{NS}$ & $9.27 \mathrm{NS}$ & 0.26 & 6.29 \\
\hline Back & $19.05 \mathrm{NS}$ & $18.67 \mathrm{NS}$ & $17.55 \mathrm{NS}$ & $16.66 \mathrm{NS}$ & $18.43 \mathrm{NS}$ & 0.17 & 9.95 \\
\hline Feet & $4.86 \mathrm{NS}$ & $4.68 \mathrm{NS}$ & $4.87 \mathrm{NS}$ & $5.00 \mathrm{NS}$ & 4.70NS & 0.90 & 12.87 \\
\hline
\end{tabular}

${ }^{1}$ Feed negative control without additives.

${ }^{2}$ Feed positive control with antimicrobials and anticoccidials.

${ }^{3}$ Control feed + essential oil of Cymbopogon flexuosus.

${ }^{4}$ Control feed + essential oil of Lippia rotundifolia.

${ }^{5}$ Control feed + association of Cymbopogon flexuosus and Lippia rotundifolia essential oils.

$\mathrm{CV}$ - coefficient of variation; NS - not significant by the Tukey test at $5 \%$ probability. 
is common among works. Silva et al. (2011) also obtained similar results using essential oil of mastic-red, compared with the negative control (without feed additives) and the positive control (ration with added zinc bacitracin and salinomycin). Shiva et al., 2012 did not detect differences between the performance of animals receiving essential oil of oregano and those receiving antibiotics (bacitracin methylene disalicylate and colistin sulfate) or no additive. Both authors highlight the lack of hygiene challenge as a cause of the resemblance. However, Cho et al. (2014) improved feed efficiency in broilers challenged with Clostridium perfringens fed diets with thyme and star anise, compared with positive (avilamycin) and negative controls.

Treatments with essential oils did not differ statistically from the positive (with antimicrobials and anticoccidials) and negative (without additives) controls $(\mathrm{P}>0.05)$ for carcass and cut yields (Table 5). Rizzo et al. (2010) analyzed broiler chickens fed diets plus commercial products containing various essential oils and also found no differences in carcass and cut yields at 44 days in animals receiving essential oils and fed diets containing avilamycin or no additive. On the other hand, Khattak et al. (2014) observed higher carcass and breast yields in animals treated with a commercial combination of essential oils of basil, cumin, bay leaf, lemon, oregano, sage, thyme, and tea, compared with the diet without additives.

The absolute and relative weights of the intestines and liver were affected by the treatments (Table 6). The values for the absolute intestine weight were lower in the treatment with the combination of essential oils, compared with treatment without additives and treatment with the lemongrass essential oil $(\mathrm{P}<0.05)$. The relative weight of intestine was higher in treatments with lemongrass essential oil and $L$. rotundifolia essential oil in relation to their combination $(\mathrm{P}<0.05)$. The reduction in intestinal weight is expected, since the use of such additives reduces the thickness of the intestinal wall. Silva et al. (2011) also observed a reduction in weight of the intestines of birds supplemented with antimicrobials and essential oil of mastic-red. However, animals that received the control diet and the diet with lemongrass essential oil presented the highest absolute and relative intestinal weights.

The relative liver weight was lower with the essential oil of lemongrass and the mix of essential oils compared with treatment with essential oil of $L$. rotundifolia $(\mathrm{P}<0.05)$. This decrease may be due to some kind of toxicity, although the animals had normal livers without macroscopic lesions.

Table 6 - Absolute and relative weight of organs of broiler chickens fed diets containing essential oils of Cymbopogon flexuosus and Lippia rotundifolia at 43 days of age

\begin{tabular}{|c|c|c|c|c|c|c|c|}
\hline Variable & $\begin{array}{l}\text { Negative } \\
\text { control }^{1}\end{array}$ & $\begin{array}{l}\text { Positive } \\
\text { control }^{2}\end{array}$ & Feed $+\mathrm{CfEO}^{3}$ & Feed $+\mathrm{LrEO}^{4}$ & $\begin{array}{c}\text { Feed }+ \\
\text { CfEO + } \text { LrEO }^{5}\end{array}$ & P-value & $\mathrm{CV}(\%)$ \\
\hline \multicolumn{8}{|c|}{ Absolute weight (g) } \\
\hline Intestine & $89.167 \mathrm{a}$ & $71.15 \mathrm{ab}$ & $93.74 \mathrm{a}$ & $73.09 \mathrm{ab}$ & $62.26 \mathrm{~b}$ & 0.00 & 19.26 \\
\hline Caecum & 11.877 & 13.50 & 13.93 & 13.73 & 11.95 & 0.81 & 30.33 \\
\hline Liver & 46.180 & 41.39 & 42.50 & 43.91 & 38.76 & 0.21 & 12.72 \\
\hline Pancreas & 5.537 & 3.21 & 4.24 & 5.78 & 5.58 & 0.08 & 36.13 \\
\hline Gizzard & 32.548 & 29.52 & 32.66 & 35.05 & 33.71 & 0.40 & 14.94 \\
\hline Bursa & 3.677 & 3.18 & 4.57 & 5.24 & 5.34 & 0.37 & 47.79 \\
\hline Spleen & 2.378 & 1.27 & 3.15 & 2.96 & 3.01 & 0.06 & 46.51 \\
\hline Heart & 10.797 & 11.21 & 11.80 & 13.10 & 11.55 & 0.67 & 23.89 \\
\hline Abdominal fat & 38.197 & 40.06 & 44.61 & 44.91 & 37.33 & 0.88 & 37.69 \\
\hline Intestine (cm) & 168.420 & 175.13 & 178.92 & 178.72 & 176.67 & 0.86 & 10.71 \\
\hline \multicolumn{8}{|c|}{ Relative weight (\%) } \\
\hline Intestine & $4.955 \mathrm{ab}$ & $3.66 \mathrm{bc}$ & $5.16 \mathrm{a}$ & $3.95 \mathrm{abc}$ & $3.52 \mathrm{c}$ & 0.00 & 18.29 \\
\hline Caecum & 0.652 & 0.69 & 0.77 & 0.74 & 0.67 & 0.83 & 29.86 \\
\hline Liver & $2.543 \mathrm{a}$ & $2.13 b$ & $2.35 \mathrm{ab}$ & $2.37 \mathrm{ab}$ & $2.17 \mathrm{~b}$ & 0.01 & 8.53 \\
\hline Pancreas & 0.307 & 0.16 & 0.23 & 0.32 & 0.31 & 0.05 & 38.29 \\
\hline Gizzard & 1.804 & 1.52 & 1.81 & 1.89 & 1.89 & 0.15 & 15.75 \\
\hline Bursa & 0.206 & 0.16 & 0.25 & 0.29 & 0.29 & 0.35 & 50.63 \\
\hline Spleen & 0.1298 & 0.06 & 0.17 & 0.16 & 0.17 & 0.04 & 47.44 \\
\hline Heart & 0.596 & 0.57 & 0.65 & 0.71 & 0.64 & 0.49 & 22.31 \\
\hline Abdominal fat & 2.109 & 2.07 & 2.49 & 2.43 & 2.07 & 0.85 & 37.52 \\
\hline
\end{tabular}

Means followed by different letters in the same row differ by the Tukey test $(\mathrm{P}<0.05)$.

${ }^{1}$ Feed negative control without additives.

${ }^{2}$ Feed positive control with antimicrobials and anticoccidials.

${ }^{3}$ Control feed + essential oil of Cymbopogon flexuosus.

${ }^{4}$ Control feed + essential oil of Lippia rotundifolia.

${ }^{5}$ Control feed + association of Cymbopogon flexuosus and Lippia rotundifolia essential oils.

$\mathrm{CV}$ - coefficient of variation. 
Data are consistent with those found by Barreto et al. (2008), who also observed lower liver weight relative to the control in chickens receiving red pepper essential oil.

The relative spleen weight was highest $(\mathrm{P}=0.044)$ in the animals fed the essential oils (lemongrass, L. rotundifolia, and combination of the two oils), showing that there was a likely effect on the immune system.

\section{Conclusions}

The trial could not find results enough to recommend the use of the lemongrass and Lippia rotundifolia essential oils as additives in broiler diets.

\section{Acknowledgments}

To Conselho Nacional de Desenvolvimento Científico e Tecnológico (CNPq), Pró-Reitoria de Pesquisa of UFMG (PRPq), Coordenação de Aperfeiçoamento de Pessoal de Nível Superior (CAPES), and Fundação de Amparo à Pesquisa do Estado de Minas Gerais (Fapemig), for the financial support provided.

\section{References}

Adukwu, E. C.; Allen, S. C. H. and Phillips, C. A. 2012. The antibiofilm activity of lemongrass (Cymbopogon flexuosus) and grapefruit (Citrus paradisi) essential oils against five strains of Staphylococcus aureus. Journal of Applied Microbiology 113:1217-1227.

Agnolin, C. A.; Olivo, C. J. and Parra, C. L. C. 2014. Efeito do óleo de capim-limão (Cymbopogon flexuosus Stapf) no controle do carrapato dos bovinos. Revista Brasileira de Plantas Medicinais 16:77-82.

Agostini, P. S.; Solá-Oriol, D.; Nofrarías, M.; Barroeta, A. C.; Gasa, J. and Manzanilla, E. G. 2012. Role of in-feed clove supplementation on growth performance, intestinal microbiology, and morphology in broiler chicken. Livestock Science 147:113-118.

Azevedo, I. L.; Almeida, A. C.; Martins, E. R.; Nogueira, W. C. L.; Faria Filho, D. E.; Oliveira, S. P.; Prates, J. P. B.; Souza, C. N. 2016. Eficácia in vitro do óleo essencial de capim-limão (cymbopogon flexuosus steud. wats.) frente a bactérias entéricas de origem avícola. Acta Veterinaria Brasilica 10:25-31.

Barreto, M. S. R.; Menten, J. F. M.; Racanicci, A. M. C.; Pereira, P. W. Z. and Rizzo, P. V. 2008. Plant extracts used as growth promoters in broilers. Revista Brasileira de Ciência Avícola 10:109-115.

Cho, J. H.; Kim, H. J. and Kim, I. H. 2014. Effects of phytogenic feed additive on growth performance, digestibility, blood metabolites, intestinal microbiota, meat color and relative organ weight after oral challenge with Clostridium perfringens in broilers. Livestock Science 160:82-88.

Desai, M. A. and Parikh, J. 2012. Hydrotropic extraction of citral from Cymbopogon flexuosus (Steud.) Wats. Industrial \& Engineering Chemical Research 51:3750-3757.

Freitas, R.; Fonseca, J. B.; Soares, R. T. R. N.; Rostagno, H. S. and Soares, P. R. 2001. Utilização do alho (Allium sativum L.) como promotor de crescimento de frangos de corte. Revista Brasileira de Zootecnia 30:761-765.

Furlan, R. L.; Macari, M. and Luquetti, B. C. 2004. Como avaliar os efeitos do uso de prebióticos, probióticos e flora de exclusão competitiva. In: Anais do $5^{\circ}$ Simpósio Técnico de Incubação, Matrizes de Corte e Nutrição, Balneário Camboriú.

Gomide, M. S.; Lemos, F. O.; Lopes, M. T. P.; Alves, T. M. A.; Viccini, L. F. and Coelho, C. M. 2013. The effect of the essential oils from five different Lippia species on the viability of tumor cell lines. Revista Brasileria de Farmacognosia 23:895-902.

Khattak, F.; Ronchi, A.; Castelli, P. and Sparks, N. 2014. Effects of natural blend of essential oil on growth performance, blood biochemistry, cecal morphology, and carcass quality of broiler chickens. Poultry Science 93:132-137.

Rizzo, P. V.; Menten, J. F. M.; Racanicci, A. M. C.; Traldi, A. B.; Silva, C. S. and Pereira, P. W. Z. 2010. Extratos vegetais em dietas para frangos de corte. Revista Brasileira de Zootecnia 39:801-807.

Rostagno, H. S.; Albino, L. F. T.; Donzele, J. L.; Gomes, P. C.; Oliveira, R.; Lopes, D. C.; Ferreira, A. S.; Barreto, S. L. T. and Euclides, R. F. 2011. Tabelas brasileiras para aves e suínos: composição de alimentos e exigências nutricionais. 3.ed. Viçosa, MG.

Santos, E. C.; Teixeira, A. S.; Freitas, R. T. F.; Rodrigues, P. B.; Dias, E. S. and Murgas, L. D. S. 2005. Uso de aditivos promotores de crescimento sobre o desempenho, características de carcaça e bactérias totais do intestino de frangos de corte. Ciência e Agrotecnologia 29:223-231.

Shiva, C.; Bernal, S.; Sauvain, M.; Caldas, J. Kalinowski, J.; Falcón, N. and Rojas, R. 2012. Evaluación del aceite esencial de orégano (Origanum Vulgare) y extracto deshidratado de jengibre (Zingiber Officinale) como potenciales promotores de crecimiento en pollos de engorde. Revista de Investigaciones Veterinarias del Perú 23:160-170.

Silva, M. A.; Pessotti, B. M. S.; Zanini, S. F.; Colnago, G. L.; Nunes, L. C.; Rodrigues, M. R. A. and Ferreira, L. 2011. Óleo essencial de aroeira-vermelha como aditivo na ração de frangos de corte. Ciência Rural 41:676-681.

Sinha, S.; Jothiramajayam, M.; Ghosh, M. and Mukherjee, A. 2014. Evaluation of toxicity of essential oils palmarosa, citronella, lemongrass and vetiver in human lymphocytes. Food and Chemical Toxicology 1:71-77.

Souza, D. S.; Almeida, A. C.; Andrade, V. A.; Marcelo, N. A.; Azevedo, I. L.; Martins, E. R. and Figueiredo, L. S. 2015. Atividade antimicrobiana do óleo essencial de Lippia origanoides e Lippia roduntifolia frente à enterobactérias isoladas de aves. Arquivo Brasileiro de Medicina Veterinaria e Zootecnia 67:940-944.

Traesel, C. K.; Lopes, S. T. A.; Wolkmer, P.; Schmidt, C.; Santurio, J. M. and Alves, S. H. 2011. Óleos essenciais como substituintes de antibióticos promotores de crescimento em frangos de corte: perfil de soroproteínas e peroxidação lipídica. Ciência Rural 41:278-284. 